\title{
In vitro antimalarial susceptibility and molecular markers of drug resistance in Franceville, Gabon
}

\author{
Rafika Zatra', Jean Bernard Lekana-douki ${ }^{1,2^{*}}$, Faustin Lekoulou', Ulrick Bisvigou ${ }^{1,3}$, Edgard Brice Ngoungou ${ }^{2}$ \\ and Fousseyni S Toure Ndouo ${ }^{1}$
}

\begin{abstract}
Background: Malaria remains a major public health problem, due largely to emergence and widespread $P$. falciparum drug resistance. WHO recommends artemisinine combination based therapy (ACT) to overcome $P$. falciparum drug resistance, but reports of declining ACT efficacy have been published. A thorough understanding of the molecular bases of $P$. falciparum resistance to existing drugs is therefore needed. The aims of this study were to analyze the in vitro sensitivity of $P$. falciparum field isolates from Franceville, Gabon, to chloroquine (CQ), mefloquine $(M F)$, dihydroartemisinine (DHA) and monodesethylamodiaquine (MDAQ), and to investigate polymorphisms associated with drug resistance.

Methods: We conducted a cross-sectional study of 53 field isolates. Field isolates sensitivity to CQ, MF, DHA and MDAQ was assessed using the colorimetric DELI test. The Pfmdr1 codons 86 and 1246, Pfcrt (haplotype codon 72 to 76) and the PfATPAse6 codons 110 and 2694 were analysed by PCR-RFLP. Associations between drug sensitivity and parasite gene polymorphisms were evaluated with the Chi square test, and routine hematological parameters were analyzed with Fisher's exact test implemented with Epinfo software. In all statistical tests, significance was assumed at $p<0.05$.
\end{abstract}

Results: A total of 46 P. falciparum isolates were successfully cultured in vitro and their sensitivity was tested. The proportions of isolates resistant to CQ, MF and MDAQ were 43.5\%, 23.4\% and 56.5\%, respectively. Some isolates (23.9\%) had DHA IC 50 values higher than $10 \mathrm{nM}$. The median IC 50 values were 71.67 (interquartile range (IQR, 1438.2), 6.59 (IQR, 0.08-96), 64.79 (IQR, 0.09-448) and $6.45 \mathrm{nM}(\mathrm{IQR}, 0.09-23)$ for CQ, MF, MDAQ and DHA, respectively. The strongest correlation between diminished DHA sensitivity and MF resistance was observed $\left(r^{2}=0.73\right)$, followed by correlation between diminished DHA sensitivity and CQ resistance. Cross-resistance between CQ and MF was also observed. The prevalence of the 86Y and 1246Y mutations in Pfmdr1, 76T in Pfcrt, and 110A and 2694T in PfATPase6 was respectively $42 \%$ and $17.1 \%, 97.8 \%$, and $0 \%$ and $22.2 \%$.

Conclusion: These high levels of antimalarial drug resistance in Franceville, Gabon, call for reinforced surveillance of drug efficacy.

\section{Background}

Despite increased funding for control programs, malaria remains a major public health problem, with approximately 781000 deaths in 2009 [1]. The reasons for this persistence include the lack of an efficacious vaccine, vector resistance to insecticides, and parasite resistance to antimalarial

\footnotetext{
* Correspondence: Lekana_jb@yahoo.fr

'Unité de Parasitologie Médicale (UPARAM), Centre International de Recherches Médicales de Franceville (CIRMF), B.P. 769 Franceville, Gabon ${ }^{2}$ Département de Parasitologie-Mycologie Médecine Tropicale, Faculté de Médecine, Université des Sciences de la Santé, B.P. 4009 Libreville, Gabon
} Full list of author information is available at the end of the article drugs. Drug resistance arises rarely but spreads relatively quickly. P. falciparum drug resistance is associated with the emergence of specific parasite genotypes [2-4] and single-nucleotide polymorphisms (SNPs) in parasite genes, including the chloroquine transporter gene Pfcrt [5,6]. Higher-level CQ resistance results from other SNPs and is negatively associated with the copy number of the $P$. falciparum multidrug resistance 1 gene Pfmdr1 [7-9]. Pfmdr1 polymorphisms also confer resistance to other antimalarial drugs, including mefloquine, lumefantrine, and quinine [9-11]. In areas where drug resistance is prevalent, WHO has recommended artemisinin-based combination therapy

\section{Biomed Central}


(ACT) for the treatment of uncomplicated falciparum malaria [12], but several reports have shown the selection of certain genotypes following ACT treatment [13-15]. Of particular concern are the results of a Pfmdr1 allelic replacement study in which various polymorphisms were found to reduce artemisinin susceptibility in cloned parasite lines [9].

Gabon is a hyperendemic country where resistance to CQ, amodiaquine and sulfadoxine-pyrimethamine is widespread [16-19]. In 2003 the National Malaria Control Program adopted the ACT strategy to treat uncomplicated malaria, instead of CQ and other monotherapies, in line with WHO recommendations. The ACTs most widely used in Gabon are artemether-lumefantrine (AL) and artesunate-mefloquine (AM). Subsequently, the prevalence of malaria among febrile children fell from $30 \%$ to $13 \%$ between 2004 and 2008, and the mean age of children with malaria rose from 24 to 41 months at the country's biggest hospital, Centre Hospitalier de Libreville (CHL) [17,20]. However, some ACT treatment failures have been observed (Kombila $M$ et al. unpublished data). In Franceville, a town of 60000 inhabitants situated in south-eastern Gabon, uncomplicated malaria has been treated with AL and AM since 2005. In this region, the few available data show prevalence rates of about 50\% for CQ resistance, $21.1 \%$ for MF resistance, and $0 \%$ for quinine resistance [18], but the prevalence of Pfcrt and Pfmdr1 genotypes is poorly documented. We recently found that the change in national antimalarial policy had led to the selection of N86 Pfmdr1 strains, whereas the prevalence of other polymorphisms in Pfmdr1 and Pfcrt remained stable [21]. Some data suggest a decline in the in vitro efficacy of artemisinin and its derivatives and also that of other drugs used in ACT regimens [22-24].

The aims of this study were 1) to determine the in vitro sensitivity of clinical P. falciparum isolates to chloroquine, mefloquine, monodesethylamodiaquine and dihydroartemisinin, and 2) to determine the prevalence of polymorphisms in the resistance-associated genes Pfmdr1, Pfcrt and PfATPase6 in Franceville, Gabon.

\section{Methods}

\section{Clinical isolates}

After obtaining informed consent from the parents or guardians, clinical isolates were collected from children infected with $P$. falciparum in both Franceville hospitals (Centre Hospitalier Régional Amissa Bongo and Hôpital de l'amitié sino-gabonaise) from October 2009 to May 2010. Giemsa-stained thin and thick blood smears were examined for $P$. falciparum mono-infection. Parasite density was determined according to Lambarené's methods [25]. If parasitemia was higher than $0.5 \%$, the sample was diluted with uninfected group $\mathrm{O}^{+}$erythrocytes before incubation with the drugs. The isolates were studied within $24 \mathrm{~h}$ following harvest. The study was approved by the Human Ethics Committee of Centre International de Recherche Médicale de Franceville.

\section{Drugs}

CQ and mefloquine (MF) were obtained from Sigma Aldrich. Dihydroartemesinine (DHA) and monoadhesylamodiaquine (MDAQ) were a gift from B. Pradines (IMTSSA, Marseille, France). The antimalarial drugs were prepared in methanol and serially diluted in complete culture medium (RPMI 1640, Gibco-BRL, Gaithersburg, MD) containing 35 mM HEPES (Sigma, St. Louis, MO), $24 \mathrm{mM}$ NaHCO3, 0.5\% Albumax (Gibco-BRL), $1 \mathrm{mg} /$ liter hypoxanthine (Sigma), and 5 $\mu \mathrm{g} / \mathrm{ml}$ gentamicin (Gibco-BRL). Cultures were synchronized with $5 \%$ sorbitol [26]. The following final drug concentrations were used: 2000, 1000, 500, 250, 125, $62.5,31.25,15.625,7.8$, and $3.9 \mathrm{nM} \mathrm{CQ}$; and 1000, 100, 50, 25, 10, 5, 1 and 0.1 nM DHA, MDAQ and MF.

\section{Maturation of $P$. falciparum isolates}

Maturation assays were performed in 96-well tissue culture plates. Each well contained $200 \mu \mathrm{L}$ of parasite suspension at $1.5 \%$ hematocrit and different drug concentrations. The plates were maintained for $40-46 \mathrm{~h}$ at $37^{\circ} \mathrm{C}$ in a candle jar as previously described [27]. Parasite growth was stopped by freezing at $-20^{\circ} \mathrm{C}$ for at least 3 hours.

\section{In vitro drug sensitivity assay}

The double-site enzyme-linked lactate dehydrogenase immunodetection (DELI) assay was used to detect P. falciparum growth as previously described [28,29]. Briefly, $100 \mu \mathrm{L}$ of lysing buffer and an appropriate volume of sample were added to MAb 17E4-precoated wells before incubation with shaking at $37^{\circ} \mathrm{C}$ for $1 \mathrm{~h}$. The plate was washed five times and $100 \mu \mathrm{L}$ of biotinylated MAb $19 \mathrm{G} 7$ was added to each well at $37^{\circ} \mathrm{C}$ for $30 \mathrm{~min}$. The plate was washed and $100 \mu \mathrm{L}$ of peroxidase-labeled streptavidin was added at $37^{\circ} \mathrm{C}$ for $15 \mathrm{~min}$. The plate was washed and $100 \mu \mathrm{L}$ of a mixture $(\mathrm{v} / \mathrm{v})$ of a peroxidase substrate solution (3,3,5,5'-tetramethylbenzidine and 0.02\% $\mathrm{H}_{2} \mathrm{O}_{2}$ ) (Kirkegaard and Perry, Gaithersburg, MD) was added and incubated in the dark for $15 \mathrm{~min}$. The reaction was stopped by adding $50 \mu \mathrm{L}$ of $1 \mathrm{M}$ phosphoric acid. The color reaction was quantified in a spectrophotometer at $450 \mathrm{~nm}$, with a reference at $630 \mathrm{~nm}$. Each experiment was performed three times in triplicate.

\section{Genetic polymorphisms in pfmdr1, pfcrt and pfATPase 6} DNA was extracted from samples by using the blood DNA OMEGA Bio-Tek E.Z.N.A. method (Omega BioTek, USA). Polymorphisms in pfcrt, pfmdr1 and Pfatpase6 
were detected by polymerase chain reaction (PCR) amplification followed by mutation-specific restriction endonuclease cleavage. Table 1 shows the primer sets and restriction enzymes used, as previously described [30], [31].

\section{Statistical analysis}

$\mathrm{IC}_{50}$ values with their $95 \%$ confidence intervals $(\mathrm{CI})$ were calculated by using an Emax model available at http:// www.antimalarial-icestimator.net, as $\mathrm{RE}=100-$ $\left[\left(100^{*} \mathrm{C}^{\gamma}\right) /\left(\mathrm{C}^{\gamma}+\mathrm{IC}_{50}^{\gamma}\right)\right]$, where $\mathrm{IC}_{50}$ is the drug concentration inhibiting $50 \%$ of parasite activity, $\gamma$ is a sigmoidicity factor which expresses the steepness of the curve, $\mathrm{RE}$ is the relative effect of the drug (in percent, Y-axis), and $\mathrm{C}$ is the drug concentration (X-axis). The $\mathrm{IC}_{50}$ cutoff values for resistance to chloroquine, mefloquine and monoadhesylamodiaquine were $100 \mathrm{nM}, 20 \mathrm{nM}, 60 \mathrm{nM}$ respectively, and the cut-off for diminished susceptibility to DHA was $10 \mathrm{nM}$. Associations between drug sensitivity and parasite gene polymorphisms were evaluated with the Chi square test, and routine hematological parameters were analyzed with Fisher's exact test implemented with Epinfo software. In all statistical tests, significance was assumed at $\mathrm{p}<0.05$.

\section{Results}

In vitro drug sensitivity of $P$. falciparum isolates

A total of 53 P. falciparum isolates were collected from Franceville hospitals. The $\mathrm{IC}_{50}$ values of all four drugs were successfully determined for 46 isolates (Figure 1). The median CQ $\mathrm{IC}_{50}$ value was 71.67 (1-438.2) $\mathrm{nM}$, and $43.5 \%(n=20)$ of isolates were CQ-resistant. The median
MDAQ $\mathrm{IC}_{50}$ value was $64.79(0.09-448) \mathrm{nM}$, and 52.2\% $(\mathrm{n}=24)$ of isolates were MDAQ-resistant. The median mefloquine $\mathrm{IC}_{50}$ value was $6.59(0.08-95.9) \mathrm{nM}$, and $23.9 \%(n=11)$ of isolates were MF-resistant. The median DHA $\mathrm{IC}_{50}$ value was $6.45(0.09-43.17) \mathrm{nM}$, and $23.9 \%$ $(n=11)$ of isolates had reduced DHA susceptibility. Ten isolates were sensitive to all four drugs. A high level of cross-resistance was observed. As shown in Table 2: The activities of DHA and MF showed the strongest correlation $\left(\mathrm{r}^{2}=0.73, \mathrm{p}<0.001\right)$. Eight of the 11 isolates with decreased DHA sensitivity were also resistant to MF. The activities of CQ and MF also showed a strong correlation $\left(\mathrm{r}^{2}=0.45, \mathrm{p}=0.04\right)$, followed by CQ and DHA $\left(\mathrm{r}^{2}=0.39, \mathrm{p}=0.006\right)$. MDAQ activity did not correlate with the activity of the other three drugs (for DHA: $\mathrm{r}^{2}=$ 0.37, $\mathrm{p}=0.08$; for $\mathrm{CQ}: \mathrm{r}^{2}=0.34, \mathrm{p}=0.5$; for $\mathrm{MF} \mathrm{r}^{2}=0.30$, $\mathrm{p}=0.08$ ) (see Table 2).

\section{Drug sensitivity and $P$. falciparum gene polymorphisms}

Table 3 shows the distribution of polymorphisms at codons 86 and 1246 in Pfmdr1 according to drug sensitivity. The overall frequencies of the wild-type (N86) Pfmdr1 and the Y86 mutation were respectively $60.1 \%$ $(\mathrm{n}=28)$ and $39.1 \%(\mathrm{n}=18)$. The Y86 mutation was not associated with CQ resistance $(30.0 \% \quad(n=6)$ in CQresistant isolates, and $42.3 \%(\mathrm{n}=11)$ in CQ-sensitive isolates, $\mathrm{p}=0.39$ ). The prevalence of the Y86 mutation was respectively $37.5 \%(\mathrm{n}=9)$ and $45.5 \%(\mathrm{n}=10), 45.5 \%(\mathrm{n}=5)$ and $34.3 \%(n=12)$, and $45.5 \%(n=5)$ and $34.3 \%(n=12)$ in MDAQ-resistant and MDAQ-sensitive isolates, MFresistant and MF-sensitive isolates, and DHA-reduced

Table 1 Sequences of primer sets and restriction enzymes used to characterized polymorphisms

\begin{tabular}{|c|c|c|c|c|c|}
\hline Genes, Codons & Primer names & Primers & $\mathrm{T}^{\circ} \mathrm{C}$ & Restriction enzyme & sizes $(b p)^{*}$ \\
\hline \multirow[t]{2}{*}{ Pfmdr1, N86Y } & mdr86D1 & TITACCGTTTAAATGTTTACCTGC & 45 & Afl III & $126+165$ \\
\hline & mdr86D2 & CCATCTTGATAAAAAACACTTCTT & & & \\
\hline \multirow[t]{2}{*}{ Pfmdr1, D1246Y, } & mdr1246D1 & AATGTAAATGAATTTTCAAACC & 45 & Bgl II & $113+90$ \\
\hline & mdr1246D2 & СATCTTCTCTTCCAAATTTGATA & & & \\
\hline \multirow[t]{2}{*}{ ATPase 6, G110A } & ATP6-110F & CGTTGAACTTATTATATCTITGTC & 60 & Mbo II & $103+94+92+40$ \\
\hline & ATP6-110R & TTCATATCTAATAAAGTTAACACG & & & \\
\hline \multirow[t]{2}{*}{ ATPase 6, A2694T } & ATP6-2694F & GAATTGTTITCTGTAGAACTGAAC & 55 & Tas I & $142+39$ \\
\hline & ATP6-2694R & ATCTGATGCTTCTITAGCTACC & & & \\
\hline \multirow[t]{2}{*}{ Pfcrt, C72S } & CRT72MS & TITATATTTAAGTATTATTTATTTAAGTGGA & 55 & Mbo I & $55+38$ \\
\hline & $76-\mathrm{D} 2$ & CAAAACTATAGTTACCAATTTG & & & \\
\hline \multirow[t]{2}{*}{ Pfcrt, M74I } & CRT745MS & TAAGTATTATTTATTTAAGTGTATGTGTCAT & 55 & Nla III & $53+31$ \\
\hline & $76-\mathrm{D} 2$ & CAAAACTATAGTTACCAATTTTG & & & \\
\hline \multirow[t]{2}{*}{ Pfcrt, N75M } & CRT745MS & TAAGTATTATTTATTTAAGTGTATGTGTCAT & 50 & BspHI & $53+31$ \\
\hline & $76-\mathrm{D} 2$ & CAAAACTATAGTTACCAATTTTG & & & \\
\hline \multirow[t]{2}{*}{ Pfcrt, 76} & Pfcrt-76A & GCGCGCGCATGGCTCACGTTTAGGTGGAG & 55 & Apo I & $136+56$ \\
\hline & Pfcrt-76B & GGGCCCGGCGGATGTTACAAAACTATAGTTACC & & & \\
\hline
\end{tabular}




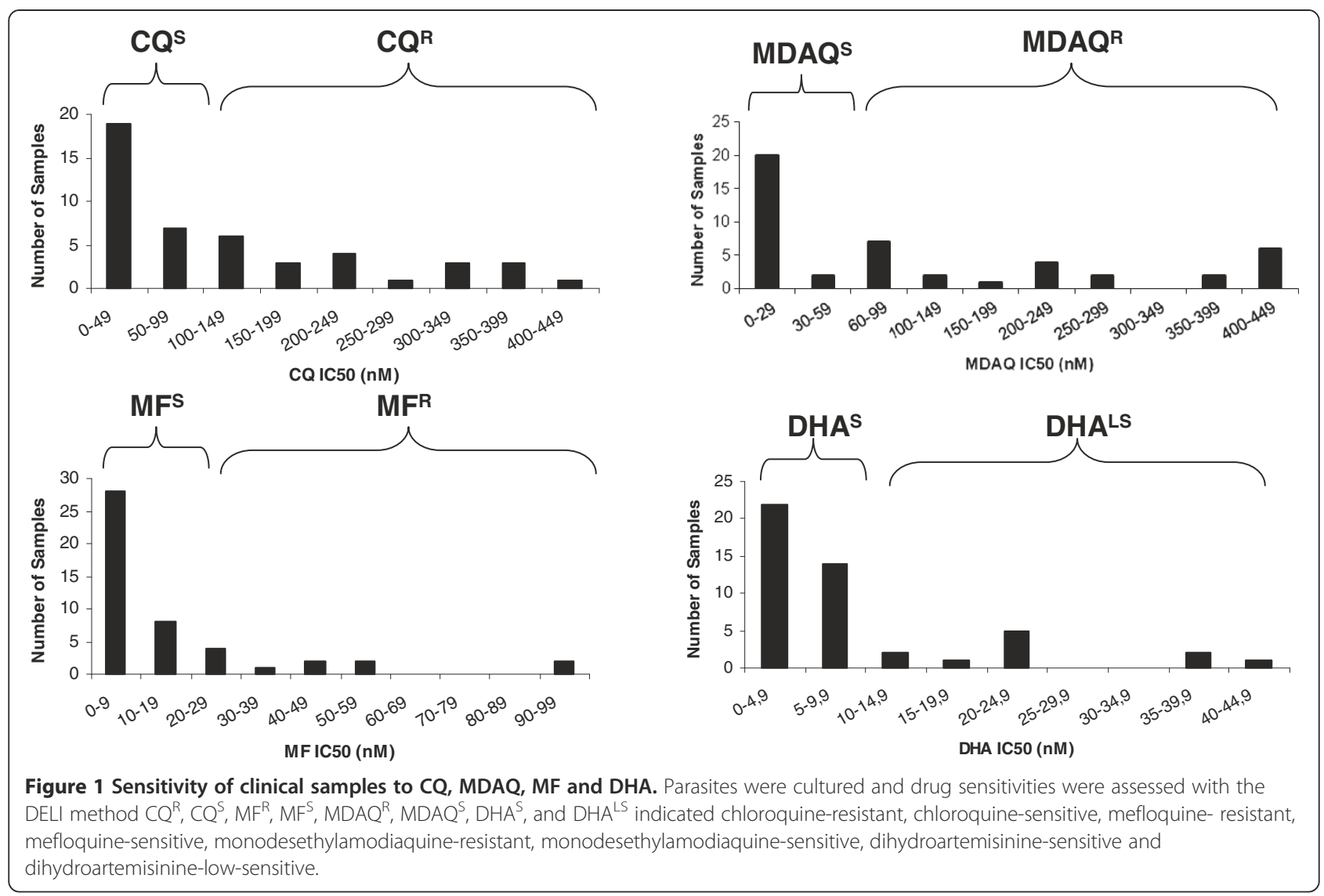

susceptibility and DHA-sensitive isolates. Only 1 mixed genotype (N/Y86) was found, and this isolate was resistant to both MDAQ and CQ. We found no association between the Y86 genotype and drug susceptibility ( $p>0.26$ ). The overall frequency of the Y1246 mutation was $17.4 \%$ in pure genotypes $(n=8)$ and $30.4 \%(n=14)$ when combined with mixed D/Y1246. The frequency of Y1246 was not different between CQ-sensitive isolates $(23.1 \%, \mathrm{n}=6)$ and CQ-resistant isolates $(10.0 \%, \mathrm{n}=2)$ $(\mathrm{p}=0.3)$. This mutant allele was carried by only 3 MDAQ-resistant isolates (12.5\%), and by none of the MDAQ-sensitive isolates. The frequency of Y1246 was $18.2 \%$ in MF-resistant isolates but only $5.7 \%$ in MFsensitive isolates $(p=0.23)$. There was no difference in the frequency of this allele between DHA-reduced

Table 2 Correlation of antimalarial activities

\begin{tabular}{llll}
\hline Drug $\mathbf{1}$ & Drug $\mathbf{2}$ & Coefficient of correlation $(\mathbf{r} \mathbf{2})$ & $\mathbf{p}$ \\
\hline DHA & MF & 0.73 & $<0.001$ \\
\hline DHA & CQ & 0.39 & 0.006 \\
\hline DHA & MDAQ & 0.37 & 0.08 \\
\hline$C Q$ & MF & 0.45 & 0.04 \\
\hline$C Q$ & $M D A Q$ & 0.34 & 0.5 \\
\hline MDAQ & MF & 0.30 & 0.08 \\
\hline
\end{tabular}

susceptibility (9.1\%) and DHA-sensitive isolates (5.7\%) $(\mathrm{p}=0.53)$. The frequency of the CVIET haplotype of Pfcrt was high (90-100\%) (Table 4). Only one isolate sensitive to $\mathrm{CQ}$ and MF and resistant to MDAQ carried the CVIEK haplotype. No association was found between this genotype and drug sensitivity $(0.23 \leq \mathrm{p} \leq 0.58)$. All the isolates were PfATPase 6 G110. The prevalence of the T2694 mutant of PfATPase 6 was $26.1 \%(n=12)$ overall and did not differ between sensitive and resistant isolates $(0.40 \leq \mathrm{p} \leq 0.60)$. The frequency of T2694 was respectively 25.0\% $(\mathrm{n}=5)$ and 19.2\% $(\mathrm{n}=5) ; 26.9 \%(\mathrm{n}=6)$ and $15.0 \%$ $(\mathrm{n}=4) ; 27.3 \%(\mathrm{n}=3)$ and $20.0 \%(\mathrm{n}=7)$; and $27.3 \%(\mathrm{n}=3)$ and $20.0 \%(\mathrm{n}=7)$ in CQ-resistant and CQ-sensitive isolates; MDAQ-resistant and MDAQ-sensitive isolates; MF-resistant and MF-sensitive isolates; and DHAreduced susceptibility and DHA-sensitive isolates (Table 5).

\section{Discussion}

This study shows that, despite the change in national antimalarial policy, the prevalence of CQ-resistant and MF-resistant isolates in Franceville, Gabon, remains stable compared with the year 2000 [18]. MDAQ resistance has not previously been investigated in Franceville. The level of MDAQ resistance found here is higher than 
Table 3 Distribution of PfMDR1 polymorphism according the status drug sensitivity groups

\begin{tabular}{|c|c|c|c|c|c|c|c|c|c|c|}
\hline \multirow[t]{3}{*}{ Drug } & \multirow[t]{3}{*}{ Profils } & \multirow[t]{3}{*}{$\mathbf{N}$} & \multicolumn{8}{|c|}{$\mathrm{N}^{\circ}(\%)$, of strains with polymorphism : (Pfmdr) } \\
\hline & & & \multicolumn{4}{|c|}{ N86Y } & \multicolumn{4}{|c|}{ D1246Y } \\
\hline & & & $\mathbf{N}$ & $\mathrm{Y}$ & MIX & p & D & $\mathrm{Y}$ & MIX & $\mathbf{p}$ \\
\hline \multirow[t]{2}{*}{ CQ } & Resistant (IC50>100 nM) & 20 & $13(65.0 \%)$ & $6(30.0 \%)$ & $1(5.0 \%)$ & 0.39 & $14(70.0 \%)$ & $2(10.0 \%)$ & $4(20.0 \%)$ & 0.3 \\
\hline & Sensitive (IC50<100 nM) & 26 & $15(57.7 \%)$ & $11(42.3 \%)$ & $0(0.0 \%)$ & & $18(69.2 \%)$ & $6(23.1 \%)$ & $2(7.7 \%)$ & \\
\hline \multirow[t]{2}{*}{ MDAQ } & Resistant (IC50 $\geq 60$ nM) & 24 & $14(58.3 \%)$ & $9(37.5 \%)$ & $1(4.2 \%)$ & 0.28 & $16(66.7 \%)$ & $3(12.5 \%)$ & $5(20.8 \%)$ & 0.09 \\
\hline & Sensitive (IC50 < 60 nM) & 22 & $12(54.5 \%)$ & $10(45.5 \%)$ & $0(0.0 \%)$ & & $20(90.9 \%)$ & $0(0.0 \%)$ & $2(9.1 \%)$ & \\
\hline \multirow[t]{2}{*}{ MF } & Resistant (IC50>20 nM) & 11 & $6(54.5 \%)$ & $5(45.5 \%)$ & $0(0.0 \%)$ & 0.7 & $7(63.6 \%)$ & $2(18.2 \%)$ & $2(18.2 \%)$ & 0.23 \\
\hline & Sensitive (IC50<20 nM) & 35 & $22(62.8 \%)$ & $12(34.3 \%)$ & $1(2,9 \%)$ & & $28(80.0 \%)$ & $2(5.7 \%)$ & $5(14.3 \%)$ & \\
\hline \multirow[t]{2}{*}{ DHA } & Reduced susceptibility (IC50 $\geq 10 \mathrm{nM}$ ) & 11 & $6(54.5 \%)$ & $5(45.5 \%)$ & $0(0.0 \%)$ & 0.7 & $9(81.8 \%)$ & $1(9.1 \%)$ & $1(9.1 \%)$ & 0.53 \\
\hline & Sensitive (IC50<10 nM) & 35 & $22(62.8 \%)$ & $12(34.3 \%)$ & $1(2.9 \%)$ & & $27(77.1 \%)$ & $2(5.7 \%)$ & $6(17.1 \%)$ & \\
\hline
\end{tabular}

that previously found in Libreville, Gabon, where $100 \%$ of isolates were susceptible to MDAQ in the year 2003 [32]. Compared with previous data from southeast of Gabon, where only $5.4 \%$ of isolates were MDAQresistant [33], we found an high prevalence of in vitro MDAQ resistance. The mean MDAQ $\mathrm{IC}_{50}$ found here is similar to that reported in Kampala, Uganda, between 2006 and 2008, after implementation of the ACT treatment policy [34]. The high level of MDAQ resistance found here could be explained by fact that amodiaquine is combined with artesunate in one of the recommended ACTs used in Gabon.

We found a high prevalence of isolates with reduced susceptibility to DHA. But, because of the brief action of DHA, this prevalence may have been overestimated. The decrease in DHA susceptibility may have arisen through the use of artemether or artesunate monotherapy to treat uncomplicated malaria, contrary to the recommendations of the Gabonese national program against malaria. Our results are in keeping with data from the capital, Libreville, where the prevalence of artemether resistance was $14 \%$, with a range of 0.8 to $34.8 \mathrm{nM}$ (mean $\mathrm{IC}_{50} 5.0 \mathrm{nM}$ ) [35]. The frequency of isolates with reduced susceptibility to DHA found here is similar to that described in Lambarené, a town situated in central Gabon [36]. We found a strong correlation between decreased susceptibility to DHA and resistance to MF and CQ. These data are consistent with previous data showing that the selection of MF resistance leads to increased resistance to artemisinin in rodent model [37], despite the fact that these drugs do not belong to the same class. Indeed, MF was used before implementation of artemisinin derivates. The correlation between MF and CQ resistance is also consistent with previous reports of cross-resistance [38]. In this case, CQ was introduced first, leading to the resistance to MF. This cross-resistance between these drugs warrants reinforced surveillance of antimalarial drug resistance in Gabon. Surprisingly, MDAQ resistance did not correlate with $C Q$ resistance, despite the facts that MDAQ and CQ belong to the same drug family and that MDAQ and CQ antimalarial activities correlate with each other [34]. However, this lack of correlation might also be explained by a lack of statistical power in our study.

Seven isolates $(11.3 \%)$ could not be cultured, possibly because of the presence of antimalarial drugs in the patients' blood that was consistent with manufacture informations.

Table 4 Distribution of PfCRT polymorphism according to the drug sensitivities

\begin{tabular}{|c|c|c|c|c|c|c|}
\hline \multirow[t]{3}{*}{ Drug } & \multirow[t]{3}{*}{ Profils } & \multirow[t]{3}{*}{$\mathbf{N}$} & \multicolumn{4}{|c|}{$\mathrm{N}^{\circ}(\%)$, of strains with polymorphism : (Pfcrt) } \\
\hline & & & \multicolumn{4}{|c|}{ HAPLOTYPE 72-76 } \\
\hline & & & CVIEK & CVIET & MIX & $\mathbf{p}$ \\
\hline \multirow[t]{2}{*}{ CQ } & Resistant (IC50 $\geq 100 \mathrm{nM})$ & 20 & $0(0.0 \%)$ & $20(100.0 \%)$ & $0(0.0 \%)$ & 0.56 \\
\hline & Sensitive (IC50 < 100 nM) & 26 & $1(3.8 \%)$ & $25(96.2 \%)$ & $0(0.0 \%)$ & \\
\hline \multirow[t]{2}{*}{ MDAQ } & Resistant (IC50 $\geq 60$ nM) & 24 & $1(4.2 \%)$ & $23(95.8 \%)$ & $0(0.0 \%)$ & 0.29 \\
\hline & Sensitive (IC50 < 60 nM) & 22 & $0(0.0 \%)$ & $22(100 \%)$ & $0(0.0 \%)$ & \\
\hline \multirow[t]{2}{*}{ MF } & Resistant (IC50 $\geq 20 \mathrm{nM}$ ) & 11 & $0(0.0 \%)$ & $11(100.0 \%)$ & $0(0.0 \%)$ & 0.58 \\
\hline & Sensitive (IC50 < 20 nM) & 35 & $1(2.9 \%)$ & $34(97.1 \%)$ & $0(0.0 \%)$ & \\
\hline \multirow[t]{2}{*}{$\mathrm{DHA}$} & Reduced susceptibility (IC50 $\geq 10 \mathrm{nM}$ ) & 11 & $1(9.1 \%)$ & $10(90.9 \%)$ & $0(0.0 \%)$ & 0.23 \\
\hline & Sensitive (IC50 < 10 nM) & 35 & $0(0.0 \%)$ & $35(100.0 \%)$ & $0(0.0 \%)$ & \\
\hline
\end{tabular}


Table 5 Distribution of A2694T PfATPase 6 polymorphism in drug sensitive groups

\begin{tabular}{|c|c|c|c|c|c|c|}
\hline \multirow[t]{2}{*}{ Drug } & \multirow[t]{2}{*}{ Profils } & \multirow[t]{2}{*}{$\mathbf{N}$} & \multicolumn{4}{|c|}{ Strains with polymorphism PfATPase 6 A2694T } \\
\hline & & & A & $\mathbf{T}$ & MIX & $\mathbf{p}$ \\
\hline \multirow[t]{2}{*}{ CQ } & Resistant (IC50>100 nM) & 20 & $14(70.0 \%)$ & $5(25.0 \%)$ & $1(5.0 \%)$ & 0.45 \\
\hline & Sensitive (IC50<100 nM) & 26 & $20(76.9 \%)$ & $5(19.2 \%)$ & $1(3.8 \%)$ & \\
\hline \multirow[t]{2}{*}{ MDAQ } & Resistant (IC50 $\geq 60$ nM) & 24 & $17(69.2 \%)$ & $6(26.9 \%)$ & $1(3.8 \%)$ & 0.6 \\
\hline & Sensitive (IC50 < 60 nM) & 22 & $17(80.0 \%)$ & $4(15.0 \%)$ & $1(5.0 \%)$ & \\
\hline \multirow[t]{2}{*}{ MF } & Resistant (IC50>20 nM) & 11 & $7(63.6 \%)$ & $3(27.3 \%)$ & $1(9.1 \%)$ & 0.4 \\
\hline & Sensitive (IC50<20 nM) & 35 & $27(77.1 \%)$ & $7(20.0 \%)$ & $1(2.9 \%)$ & \\
\hline \multirow[t]{2}{*}{$\mathrm{DHA}$} & Reduced susceptibility (IC50 $\geq 10 \mathrm{nM}$ ) & 11 & $8(72.7 \%)$ & $3(27.3 \%)$ & $0(0.0 \%)$ & 0.4 \\
\hline & Sensitive $(I C 50<10 \mathrm{nM})$ & 35 & $26(74.3 \%)$ & $7(20.0 \%)$ & $2(5.71 \%)$ & \\
\hline
\end{tabular}

Previous reports indicate that the use of artemetherlumefantrine is associated with the selection of Pfmdr1N86 wild-type parasites, which are tolerant of low LM concentrations [15,39-41]. The present data confirm those of our previous study showing an increase in Pfmdr1-N86 genotype field isolates in Franceville after implementation of the ACT treatment policy [21]. In comparison with the prevalence of N86 in 2004 (15.6\%) and 2009 (31.3\%), this gradual increase calls for reinforced surveillance of artemether-lumefantrine resistance.

A correlation between the Pfmdr1 Y86 and Y1246 mutations and both $\mathrm{CQ}$ and MDAQ resistances has been reported [34,42], but we did not find this correlation. Surprisingly, the Pfmdr1 N86Y polymorphism was not associated with decreased sensitivity in this study. This is, however, consistent with data from Lambarené (central Gabon), where Y86 was not found to be associated with CQ resistance in 1998 [43], before implementation of ACT: in this latter study the prevalence of N86 was 20.5\% and the Y1246 mutation was not detected. Our data suggest the spread of the Y1246 mutation in Gabon. The 184F mutation was not analysed, as its impact on drug resistance is controversial [14,44], but this mutation has been identified as an independent marker of decreased lumefantrine susceptibility [45] and it will be interesting to investigate it in our study region.

The Pfmdr1 copy number was not investigated here, as it has not been consistently linked to ACT treatment failure [22,31], and this is one of limitations of our study. Indeed, it has been shown that increased a Pfmdr1 copy number is associated with reduced in vitro susceptibility to mefloquine, lumefantrine and artesunate [22].

While Pfcrt CVIET is the most prevalent haplotype in Africa, the SVMNT haplotype has recently migrated to Tanzania and Angola [46,47]. This haplotype, which has relatively little fitness cost, has been associated with emergence of AQ resistance $[48,49]$. Thus, it is crucial to monitor Pfcrt codons $72-76$ in all countries in which AQ combination therapy is recommended. Because of human migration between Angola and Gabon, we investigated the
Pfcrt haplotype 72-76 in our isolates: only haplotypes CVIET and CVIEK were detected. The high prevalence of CVIET ( $n=45 / 46)$ made it difficult to show a significant difference in the distribution of polymorphisms between resistant and sensitive isolates. This haplotype is associated with resistance against 4-aminoquinoline. The persistently high frequency of CVIET, despite the withdrawal of CQ in Gabon, could be due to use of amodiaquine as a partner in some ACTs. Recently, CVIET was also reported to be associated with reduced sensitivity to new 4-aminoquinolines such as piperaquine [50].

Polymorphisms in the putative drug transporter PfATPase6 were not closely linked to in vitro drug sensitivity, in keeping with data from Cameroon, a neighboring country [51]. No mutations were found at codon 110. The E431K, A623E, and S769N polymorphisms were not analysed, because of their rarity in sub-Saharan Africa and their lack of impact on in vitro drug resistance [51-53].

\section{Conclusion}

Our results confirm that Franceville, Gabon, is an area with high levels of $P$. falciparum in vitro drug resistance and a particularly high frequency of reduced DHA sensitivity. Polymorphisms associated with drug resistance are highly prevalent. This underlines the need for in vitro and molecular surveillance of antimalarial drug resistance.

\section{Competing interests}

The authors declare that they have no competing interests.

\section{Authors' contributions}

$R Z$ conducted this study and participated in the writing of this paper, JBLD conceived this work, conducted study and wrote the article, FL participated in the study as a technician, UB participated in the study as a clinician, EBN participated in the statistical analyses, and in the writing of the paper, and FSTN coordinated the realization of the study and writing of the paper. All authors read and approved the final manuscript.

\section{Acknowledgments}

We thank Dr B. Pradines for kindly donating dihydroartemisinin and monodesethylamodiaquine. We are grateful to the children and their parents who accepted to participate in the study, and to the staff of the pediatric wards (particularly Dr Okagna and Dr Ekaghba, Patrician, Michel and Tiburce 
of LAM of Centre Hospitalier Régional Amissa Bongo and Hôpital de l'Amitié Sino-Gabonaise, Franceville. We also thank the staff of the Medical Parasitology Unit at Centre International de Recherches Médicales de Franceville (CIRMF).

\section{Author details}

${ }^{1}$ Unité de Parasitologie Médicale (UPARAM), Centre International de Recherches Médicales de Franceville (CIRMF), B.P. 769 Franceville, Gabon. ${ }^{2}$ Département de Parasitologie-Mycologie Médecine Tropicale, Faculté de Médecine, Université des Sciences de la Santé, B.P. 4009 Libreville, Gabon. ${ }^{3}$ Département de Santé Publique et de Médecine Légale et du Travail, Faculté de Médecine, Université des Sciences de la Santé, B.P. 4009 Libreville, Gabon.

Received: 14 July 2011 Accepted: 29 October 2012 Published: 15 November 2012

\section{References}

1. WHO: World Malaria Report 2010. Geneva: World Health Organization; 2010:32.

2. Wang P, Read M, Sims PF, Hyde JE: Sulfadoxine resistance in the human malaria parasite Plasmodium falciparum is determined by mutations in dihydropteroate synthetase and an additional factor associated with folate utilization. Mol Microbiol 1997, 23(5):979-986.

3. Basco LK, Tahar R, Ringwald P: Molecular basis of in vivo resistance to sulfadoxine-pyrimethamine in African adult patients infected with Plasmodium falciparum malaria parasites. Antimicrob Agents Chemother 1998, 42(7):1811-1814.

4. Djimde A, Doumbo OK, Cortese JF, Kayentao K, Doumbo S, Diourte Y, Dicko A, Su XZ, Nomura T, Fidock DA, et al: A molecular marker for chloroquineresistant falciparum malaria. N Engl J Med 2001, 344(4):257-263.

5. Basco LK, Ndounga M, Ngane VF, Soula G: Molecular epidemiology of malaria in Cameroon. XIV. Plasmodium falciparum chloroquine resistance transporter (PFCRT) gene sequences of isolates before and after chloroquine treatment. Am J Trop Med Hyg 2002, 67(4):392-395.

6. Fidock DA, Nomura T, Talley AK, Cooper RA, Dzekunov SM, Ferdig MT, Ursos $L M$, Sidhu AB, Naude B, Deitsch KW, et al: Mutations in the P. falciparum digestive vacuole transmembrane protein PfCRT and evidence for their role in chloroquine resistance. Mol Cell 2000, 6(4):861-871.

7. Foote SJ, Kyle DE, Martin RK, Oduola AM, Forsyth K, Kemp DJ, Cowman AF: Several alleles of the multidrug-resistance gene are closely linked to chloroquine resistance in Plasmodium falciparum. Nature 1990, 345(6272):255-258.

8. Pickard AL, Wongsrichanalai C, Purfield A, Kamwendo D, Emery K, Zalewski C, Kawamoto F, Miller RS, Meshnick SR: Resistance to antimalarials in Southeast Asia and genetic polymorphisms in pfmdr1. Antimicrob Agents Chemother 2003, 47(8):2418-2423.

9. Reed MB, Saliba KJ, Caruana SR, Kirk K, Cowman AF: Pgh1 modulates sensitivity and resistance to multiple antimalarials in Plasmodium falciparum. Nature 2000, 403(6772):906-909.

10. Peel SA, Bright P, Yount B, Handy J, Baric RS: A strong association between mefloquine and halofantrine resistance and amplification, overexpression, and mutation in the P-glycoprotein gene homolog (pfmdr) of Plasmodium falciparum in vitro. Am J Trop Med Hyg 1994 51(5):648-658.

11. Cowman AF, Galatis D, Thompson JK: Selection for mefloquine resistance in Plasmodium falciparum is linked to amplification of the pfmdr1 gene and cross-resistance to halofantrine and quinine. Proc Natl Acad Sci U S A 1994, 91(3):1143-1147.

12. Nosten F, White NJ: Artemisinin-based combination treatment of falciparum malaria. Am J Trop Med Hyg 2007, 77(6 Suppl):181-192.

13. Alam MT, de Souza DK, Vinayak S, Griffing SM, Poe AC, Duah NO, Ghansah A, Asamoa K, Slutsker L, Wilson MD, et al: Selective sweeps and genetic lineages of Plasmodium falciparum drug -resistant alleles in Ghana. $J$ Infect Dis 2011, 203(2):220-227.

14. Some AF, Sere YY, Dokomajilar C, Zongo I, Rouamba N, Greenhouse B, Ouedraogo JB, Rosenthal PJ: Selection of known Plasmodium falciparum resistance-mediating polymorphisms by artemether-lumefantrine and amodiaquine-sulfadoxine-pyrimethamine but not dihydroartemisininpiperaquine in Burkina Faso. Antimicrob Agents Chemother 2010, 54(5):1949-1954.
15. Sisowath C, Stromberg J, Martensson A, Msellem M, Obondo C, Bjorkman A, Gil JP: In vivo selection of Plasmodium falciparum pfmdr1 $86 \mathrm{~N}$ coding alleles by artemether-lumefantrine (Coartem). J Infect Dis 2005, 191(6):1014-1017.

16. Aubouy A, Bakary M, Keundjian A, Mbomat B, Makita JR, Migot-Nabias F, Cot $M$, Le Bras J, Deloron P: Combination of drug level measurement and parasite genotyping data for improved assessment of amodiaquine and sulfadoxine-pyrimethamine efficacies in treating Plasmodium falciparum malaria in Gabonese children. Antimicrob Agents Chemother 2003, 47(1):231-237.

17. Nsimba B, Guiyedi V, Mabika-Mamfoumbi M, Mourou-Mbina JR, Ngoungou E, Bouyou-Akotet M, Loembet R, Durand R, Le Bras J, Kombila M: Sulphadoxine/pyrimethamine versus amodiaquine for treating uncomplicated childhood malaria in Gabon: a randomized trial to guide national policy. Malar J 2008, 7:31.

18. Ndong JM, Atteke C, Aubouy A, Bakary M, Lebibi J, Deloron P: In vitro activity of chloroquine, quinine, mefloquine and halofantrine against Gabonese isolates of Plasmodium falciparum. Trop Med Int Health 2003, 8(1):25-29.

19. Ramharter $M$, Wernsdorfer $W H$, Kremsner PG: In vitro activity of quinolines against Plasmodium falciparum in Gabon. Acta Trop 2004, 90(1):55-60.

20. Bouyou-Akotet MK, Mawili-Mboumba DP, Kendjo E, Mabika-Mamfoumbi M, Ngoungou EB, Dzeing-Ella A, Pemba-Mihindou M, Ibinga E, Efame-Eya E, Planche $T$, et al: Evidence of decline of malaria in the general hospital of Libreville, Gabon from 2000 to 2008. Malar J 2009, 8(1):300.

21. Lekana-Douki JB, Boutamba SD, Zatra R, Edou SE, Ekomy H, Bisvigou U, Toure-Ndouo FS: Increased prevalence of the Plasmodium falciparum Pfmdr1 86N genotype among field isolates from Franceville, Gabon after replacement of chloroquine by artemether-lumefantrine and artesunatemefloquine. Infect Genet Evol 2011, 11(2):512-517.

22. Lim P, Alker AP, Khim N, Shah NK, Incardona S, Doung S, Yi P, Bouth DM, Bouchier C, Puijalon OM, et al: Pfmdr1 copy number and arteminisin derivatives combination therapy failure in falciparum malaria in Cambodia. Malar J 2009, 8:11.

23. Pascual A, Basco LK, Baret E, Amalvict R, Travers D, Rogier C, Pradines B: Use of the atmospheric generators for capnophilic bacteria Genbag-CO2 for the evaluation of in vitro Plasmodium falciparum susceptibility to standard anti-malarial drugs. Malar J 2011, 10(1):8.

24. Okombo J, Kiara SM, Rono J, Mwai L, Pole L, Ohuma E, Borrmann S, Ochola LI, Nzila A: In vitro activities of quinine and other antimalarials and pfnhe polymorphisms in Plasmodium isolates from Kenya. Antimicrob Agents Chemother 2010, 54(8):3302-3307.

25. Planche T, Krishna S, Kombila M, Engel K, Faucher JF, Ngou-Milama E, Kremsner PG: Comparison of methods for the rapid laboratory assessment of children with malaria. Am J Trop Med Hyg 2001, 65(5):599-602.

26. Douki JB, Sterkers Y, Lepolard C, Traore B, Costa FT, Scherf A, Gysin J: Adhesion of normal and Plasmodium falciparum ring-infected erythrocytes to endothelial cells and the placenta involves the rhoptryderived ring surface protein-2. Blood 2003, 101(12):5025-5032.

27. Trager W, Jensen JB: Human malaria parasites in continuous culture. Science 1976, 193(4254):673-675.

28. Druilhe P, Moreno A, Blanc C, Brasseur PH, Jacquier P: A colorimetric in vitro drug sensitivity assay for Plasmodium falciparum based on a highly sensitive double-site lactate dehydrogenase antigen-capture enzyme-linked immunosorbent assay. Am J Trop Med Hyg 2001, 64(5-6):233-241.

29. Kaddouri H, Nakache S, Houze S, Mentre F, Le Bras J: Assessment of the drug susceptibility of Plasmodium falciparum clinical isolates from africa by using a Plasmodium lactate dehydrogenase immunodetection assay and an inhibitory maximum effect model for precise measurement of the 50-percent inhibitory concentration. Antimicrob Agents Chemother 2006, 50(10):3343-3349.

30. Duraisingh MT, Jones $P$, Sambou I, von Seidlein L, Pinder M, Warhurst DC: The tyrosine- 86 allele of the pfmdr 1 gene of Plasmodium falciparum is associated with increased sensitivity to the anti-malarials mefloquine and artemisinin. Mol Biochem Parasitol 2000, 108(1):13-23.

31. Happi CT, Gbotosho GO, Folarin OA, Sowunmi A, Hudson T, O'Neil M, Milhous W, Wirth DF, Oduola AM: Selection of Plasmodium falciparum multidrug resistance gene 1 alleles in asexual stages and gametocytes 
by artemether-lumefantrine in Nigerian children with uncomplicated falciparum malaria. Antimicrob Agents Chemother 2009, 53(3):888-895.

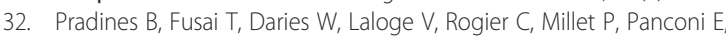
Kombila M, Parzy D: Ferrocene-chloroquine analogues as antimalarial agents: in vitro activity of ferrochloroquine against 103 Gabonese isolates of Plasmodium falciparum. J Antimicrob Chemother 2001, 48(2):179-184

33. Aubouy A, Mayombo J, Keundjian A, Bakary M, Le Bras J, Deloron P: Short report: lack of prediction of amodiaquine efficacy in treating Plasmodium falciparum malaria by in vitro tests. Am J Trop Med Hyg 2004, 71(3):294-296.

34. Nsobya SL, Kiggundu M, Nanyunja S, Joloba M, Greenhouse B, Rosenthal PJ: In vitro sensitivities of Plasmodium falciparum to different antimalarial drugs in Uganda. Antimicrob Agents Chemother 2010, 54(3):1200-1206.

35. Pradines B, Mabika Mamfoumbi M, Parzy D, Owono Medang M, Lebeau C, Mourou Mbina JR, Doury JC, Kombila M: In vitro susceptibility of Gabonese wild isolates of Plasmodium falciparum to artemether, and comparison with chloroquine, quinine, halofantrine and amodiaquine. Parasitology 1998, 117(Pt 6):541-545.

36. Philipps J, Radloff PD, Wernsdorfer W, Kremsner PG: Follow-up of the susceptibility of Plasmodium falciparum to antimalarials in Gabon. Am Trop Med Hyg 1998, 58(5):612-618.

37. Peters W, Howells RE, Portus J, Robinson BL, Thomas S, Warhurst DC: The chemotherapy of rodent malaria, XXVII. Studies on mefloquine (WR 142,490). Ann Trop Med Parasitol 1977, 71(4):407-418.

38. Platel DF, Mangou F, Tribouley-Duret J: High-level chloroquine resistance of Plasmodium berghei is associated with multiple drug resistance and loss of reversal by calcium antagonists. Int J Parasitol 1998, 28(4):641-651.

39. Dahlstrom S, Ferreira PE, Veiga MI, Sedighi N, Wiklund L, Martensson A, Farnert A, Sisowath C, Osorio L, Darban H, et al: Plasmodium falciparum multidrug resistance protein 1 and artemisinin-based combination therapy in Africa. J Infect Dis 2009, 200(9):1456-1464.

40. Dokomajilar C, Lankoande ZM, Dorsey G, Zongo I, Ouedraogo JB, Rosenthal $P J$ : Roles of specific Plasmodium falciparum mutations in resistance to amodiaquine and sulfadoxine-pyrimethamine in Burkina Faso. Am J Trop Med Hyg 2006, 75(1):162-165.

41. Raman J, Mauff K, Muianga P, Mussa A, Maharaj R, Barnes Kl: Five years of antimalarial resistance marker surveillance in Gaza Province, Mozambique, following artemisinin-based combination therapy roll out PloS One 2011, 6(10):e25992.

42. Mwai L, Kiara SM, Abdirahman A, Pole L, Rippert A, Diriye A, Bull P, Marsh K, Borrmann S, Nzila A: In vitro activities of piperaquine, lumefantrine, and dihydroartemisinin in Kenyan Plasmodium falciparum isolates and polymorphisms in pfcrt and pfmdr1. Antimicrob Agents Chemother 2009, 53(12):5069-5073.

43. Grobusch MP, Adagu IS, Kremsner PG, Warhurst DC: Plasmodium falciparum: in vitro chloroquine susceptibility and allele-specific PCR detection of Pfmdr1 Asn86Tyr polymorphism in Lambarene, Gabon. Parasitology 1998, 116(Pt 3):211-217.

44. Dlamini SV, Beshir K, Sutherland CJ: Markers of anti-malarial drug resistance in Plasmodium falciparum isolates from Swaziland: identification of pfmdr1-86F in natural parasite isolates. Malar J 2010, 9:68.

45. Mungthin M, Khositnithikul R, Sitthichot N, Suwandittakul N, Wattanaveeradej V, Ward SA, Na-Bangchang K: Association between the pfmdr1 gene and in vitro artemether and lumefantrine sensitivity in Thai isolates of Plasmodium falciparum. Am J Trop Med Hyg 2010, 83(5):1005-1009.

46. Alifrangis M, Dalgaard MB, Lusingu JP, Vestergaard LS, Staalsoe $T$, Jensen AT, Enevold A, Ronn AM, Khalil IF, Warhurst DC, et al: Occurrence of the Southeast Asian/South American SVMNT haplotype of the chloroquineresistance transporter gene in Plasmodium falciparum in Tanzania. $J$ Infect Dis 2006, 193(12):1738-1741.

47. Gama BE, Pereira-Carvalho GA, Lutucuta Kosi FJ, de Oliveira NK A, Fortes F, Rosenthal PJ, Daniel-Ribeiro CT, De Fatima Ferreira-da-Cruz M: Plasmodium falciparum isolates from Angola show the StctVMNT haplotype in the pfcrt gene. Malar J 2010, 9:174.

48. Warhurst DC: Polymorphism in the Plasmodium falciparum chloroquineresistance transporter protein links verapamil enhancement of chloroquine sensitivity with the clinical efficacy of amodiaquine. Malar J 2003, 2:31
49. Beshir K, Sutherland CJ, Merinopoulos I, Durrani N, Leslie T, Rowland M, Hallett RL: Amodiaquine resistance in Plasmodium falciparum malaria in Afghanistan is associated with the pfcrt SVMNT allele at codons 72 to 76. Antimicrob Agents Chemother 2010, 54(9):3714-3716.

50. Muangnoicharoen S, Johnson DJ, Looareesuwan S, Krudsood S, Ward SA: Role of known molecular markers of resistance in the antimalarial potency of piperaquine and dihydroartemisinin in vitro. Antimicrob Agents Chemother 2009, 53(4):1362-1366.

51. Tahar R, Ringwald P, Basco LK: Molecular epidemiology of malaria in Cameroon. XXVIII. In vitro activity of dihydroartemisinin against clinical isolates of Plasmodium falciparum and sequence analysis of the $P$. falciparum ATPase 6 gene. Am J Trop Med Hyg 2009, 81(1):13-18.

52. Ibrahim ML, Khim N, Adam HH, Ariey F, Duchemin JB: Polymorphism of PfATPase in Niger: detection of three new point mutations. Malar J 2009, 8:28.

53. Dahlstrom S, Veiga MI, Ferreira P, Martensson A, Kaneko A, Andersson B, Bjorkman A, Gil JP: Diversity of the sarco/endoplasmic reticulum $\mathrm{Ca}(2+)$-ATPase orthologue of Plasmodium falciparum (PfATP6). Infect Genet Evol 2008, 8(3):340-345

doi:10.1186/1471-2334-12-307

Cite this article as: Zatra et al.: In vitro antimalarial susceptibility and molecular markers of drug resistance in Franceville, Gabon. BMC Infectious Diseases 2012 12:307.

\section{Submit your next manuscript to BioMed Central and take full advantage of:}

- Convenient online submission

- Thorough peer review

- No space constraints or color figure charges

- Immediate publication on acceptance

- Inclusion in PubMed, CAS, Scopus and Google Scholar

- Research which is freely available for redistribution 